\title{
Analisis Suseptibilitas Magnetik dan Kandungan Logam Berat pada Tanah Lapisan Atas di Sekitar Pabrik PT Semen Padang
}

\author{
Yulistio Martha*, Arif Budiman \\ Laboratorium Fisika Bumi, Jurusan Fisika \\ Fakultas Matematika dan Ilmu Pengetahuan Alam, Universitas Andalas \\ Kampus Unand Limau Manis, Padang, 25163 Indonesia \\ *yulistiomartha@gmail.com
}

\begin{abstract}
ABSTRAK
Telah dilakukan identifikasi logam berat pada tanah lapisan atas dengan menggunakan metode suseptibilitas magnetik dan spektrometri di sekitar pabrik PT Semen Padang. Sampel tanah diambil sedalam $10 \mathrm{~cm}$ dari permukaan tanah sebanyak 30 titik. Tanah yang mengandung logam berat memiliki nilai suseptibilitas magnetik yang lebih tinggi daripada tanah yang tidak mengandung logam berat. Pengukuran nilai suseptibilitas magnetik dilakukan dengan menggunakan Bartington Magnetic Susceptibility Meter dengan sensor MS2B pada 15 arah yang berbeda. Data yang diperoleh diolah dengan menggunakan program Matlab 2015a. Hasil perhitungan menunjukkan bahwa sampel memiliki nilai suseptibilitas magnetik yang berkisar dari $213,9 \times 10^{-8} \mathrm{~m}^{3} / \mathrm{kg}$ sampai $2218,9 \times 10^{-8} \mathrm{~m}^{3} / \mathrm{kg}$ dengan rata-rata $686,9 \times 10^{-8} \mathrm{~m}^{3} / \mathrm{kg}$. Berdasarkan hasil pemetaan nilai suseptibilitas magnetik menggunakan program Surfer 11, penyebaran nilai suseptibilitas magnetik yang lebih tinggi terdapat di daerah sisi selatan PT Semen Padang. Penentuan jenis dan konsentrasi logam berat dilakukan pada lima sampel uji (P24, P16, P14, J2, dan J4) dengan menggunakan alat X-Ray Fluorescence (XRF) Panalytical Epsilon 3. Hasil XRF menunjukkan bahwa kelima sampel uji mengandung logam berat $\mathrm{Cr}, \mathrm{Cu}, \mathrm{Fe}, \mathrm{Ni}, \mathrm{Pb}$, dan $\mathrm{Zn}$ yang melebihi ambang batas kecuali pada sampel P24 untuk logam berat Ni dan Pb. Berdasarkan hubungan antara nilai suseptibilitas magnetik dan konsentrasi logam berat pada kelima sampel uji dapat disimpulkan bahwa hampir semua sampel yang diambil di sekitar PT Semen Padang mengandung logam berat yang melebihi ambang batas. Secara umum, nilai suseptibilitas magnetik dan konsentrasi logam berat mengalami peningkatan selama enam tahun terakhir.

Kata kunci: logam berat, tanah lapisan atas, suseptibilitas magnetik.
\end{abstract}

\begin{abstract}
Heavy metals in topsoil around PT Semen Padang factory were identified by using magnetic susceptibility and spectrometry methods. Soil samples were taken within $10 \mathrm{~cm}$ from soil surface for 30 points. Soils containing heavy metals have higher magnetic susceptibility values than soils without containing heavy metals. Magnetic susceptibility value was measured by using Bartington Magnetic Susceptibility Meter with MS2B censor of 15 different directions. Output data were processed by using Matlab 2015 a program. The results showed that the samples have a magnetic susceptibility value from $213,9 \times 10^{-8} \mathrm{~m}^{3} / \mathrm{kg}$ until $2218,9 \times 10^{-8} \mathrm{~m}^{3} / \mathrm{kg}$ with average $686,9 \times 10^{-8} \mathrm{~m}^{3} / \mathrm{kg}$. Based on magnetic susceptibility mapping using Surfer 11 program, deployment of magnetic susceptibility value is higher in the Southern area of PT Semen Padang. Type and concentration of heavy metals were determined on five test samples (P24, P16, P14, J2, and J4) by using X-Ray Fluorescence (XRF) Panalytical Epsilon 3. The results of XRF showed that five test samples contained $\mathrm{Cr}, \mathrm{Cu}, \mathrm{Fe}, \mathrm{Ni}, \mathrm{Pb}$, and $\mathrm{Zn}$ that exceed the threshold except the P24 sample for Ni and Pb. Based on the correlation between magnetic susceptibility value and heavy metal concentration on five test samples, it can be concluded that almost all samples were taken around PT Semen Padang contained heavy metals that exceed the threshold. In general, magnetic susceptibility value and heavy metal concentration have increased over in the last six years. Keywords: heavy metal, topsoil, magnetic susceptibility.
\end{abstract}

\section{PENDAHULUAN}

Tanah merupakan bagian lapisan kerak bumi yang tersusun dari bahan mineral dan bahan organik. Tanah terdiri dari empat lapisan, yaitu lapisan atas, lapisan tengah, lapisan bawah, dan lapisan batuan induk. Tanah lapisan atas memiliki kedalaman hingga $25 \mathrm{~cm}$. Tanah lapisan atas dapat dijadikan sebagai indikator untuk mengetahui kualitas lingkungan hidup (Rochyatun dan Rozak, 2007; Lu dkk., 2010). Tanah lapisan atas merupakan tempat hidupnya tumbuhan yang merupakan produsen utama dari rantai makanan dan juga sebagai penerima dari berbagai macam polutan, terutama logam berat (Sutanto, 2005). Logam berat merupakan bahan 
pencemar yang berbahaya, karena logam berat tidak dapat dihancurkan (non degradable) oleh organisme hidup di dalam tanah.

Di daerah perkotaan, pencemaran logam berat pada tanah lapisan atas disebabkan oleh emisi pabrik dan kendaraan bermotor. Emisi tersebut berupa gas $\left(\mathrm{CO}, \mathrm{CO}_{2}, \mathrm{HC}, \mathrm{NOx}\right.$, dan $\left.\mathrm{SO}_{2}\right)$ dan partikulat logam berat ( $\mathrm{As}, \mathrm{Cd}, \mathrm{Co}, \mathrm{Ni}, \mathrm{Pb}, \mathrm{Zn}$, dan lain-lain) (Radojević dan Bashkin, 1999). Reaksi emisi gas dengan air hujan akan menghasilkan hujan asam. Hujan asam dapat membebaskan ikatan logam berat yang terperangkap dalam tanah, sehingga menambah jumlah logam berat pada tanah (Worsztynowicz dan Mill, 1995).

Logam berat pada umumnya merupakan mineral magnetik dengan nilai suseptibilitas magnetik yang tinggi. Suseptibilitas magnetik merupakan parameter kerentanan suatu bahan terhadap pengaruh medan magnetik luar. Tanah yang mengandung logam berat akan memiliki nilai suseptibilitas magnetik yang lebih tinggi daripada tanah yang tidak mengandung logam berat (Lu dkk., 2010; Kucer dkk., 2012; Brempong dkk., 2016).

Metode yang umum digunakan untuk mengidentifikasi logam berat adalah spektrometri, dengan menggunakan beberapa alat seperti Atomic Absorption Spectroscopy (AAS), UV-Vis Spectrometry, Inductively Coupled Plasma (ICP), dan X-Ray Fluorescence (XRF). Akan tetapi metode tersebut membutuhkan waktu yang lama dan biaya yang besar jika diterapkan pada penelitian yang melibatkan sampel yang sangat banyak. Untuk mengatasi hal tersebut dapat digunakan metode suseptibilitas magnetik terlebih dahulu, karena metode ini dapat dilakukan dengan cepat, mudah, dan ekonomis (Wang, 2013).

Pabrik semen merupakan salah satu industri penyumbang emisi logam berat terbesar. Emisi logam berat yang dihasilkan pabrik semen adalah $\mathrm{Cd}, \mathrm{Co}, \mathrm{Cr}, \mathrm{Cu}, \mathrm{Fe}, \mathrm{Ni}, \mathrm{Pb}$, dan $\mathrm{Zn}$ ( $\mathrm{Al}-$ Khashman dan Shawabkeh, 2006; Bermudez dkk., 2010; Ogunkunle dan Fatoba, 2014). PT Semen Padang merupakan industri semen pertama di Indonesia yang telah beroperasi sejak tanggal 18 Maret 1910. PT Semen Padang memiliki pabrik yang terletak di daerah Indarung, Kecamatan Lubuk Kilangan, Kota Padang. Saat ini di sekitar pabrik tersebut banyak terdapat pemukiman penduduk. Emisi dari aktivitas pabrik diperkirakan akan memberikan dampak buruk bagi lingkungan sekitarnya.

Afdal dan Yulius (2012) telah melakukan penelitian untuk mengetahui sebaran logam berat di beberapa ruas jalan di sekitar PT Semen Padang. Penelitian tersebut menggunakan metode suseptibilitas magnetik dan AAS. Hasil penelitian menunjukkan bahwa logam berat yang diidentifikasi yaitu $\mathrm{Al}, \mathrm{Cd}, \mathrm{Cr}, \mathrm{Cu}, \mathrm{Pb}$, dan $\mathrm{Zn}$, yang didominasi oleh logam berat $\mathrm{Al}$. Mengingat pada penelitian tersebut sampel diambil di pinggir jalan utama, diperkirakan bahwa logam berat pada sampel dominan berasal dari emisi kendaraan bermotor. Hal ini menunjukkan bahwa kontribusi logam berat yang berasal dari emisi pabrik PT Semen Padang terhadap pencemaran lingkungan belum dapat dipastikan. Oleh karena itu perlu dilakukan penelitian kembali untuk melengkapi penelitian sebelumnya dengan melakukan pengambilan sampel di pemukiman penduduk yang relatif tidak terlalu dekat dengan jalan utama. Di samping itu juga dilakukan pengambilan sampel di dekat jalan utama untuk mengkonfirmasi penelitian sebelumnya.

\section{METODE}

Pengambilan sampel sebanyak 30 titik dilakukan di beberapa ruas jalan utama dan di pemukiman penduduk dalam radius $1 \mathrm{~km}$ di sekitar pabrik PT Semen Padang seperti yang ditunjukkan oleh Gambar 1. Titik sampel di beberapa ruas jalan utama merupakan titik sampel yang sama dengan penelitian sebelumnya (Afdal dan Yulius, 2012) untuk mengetahui laju peningkatan pencemaran logam berat selama enam tahun terakhir. Sampel yang diambil berupa tanah lapisan atas pada kedalaman $10 \mathrm{~cm}$ dari permukaan tanah. Sampel diambil menggunakan pipa PVC, kemudian dimasukkan ke dalam plastik ziplock, lalu dibawa ke Laboratorium Fisika Bumi Universitas Andalas. Sampel yang telah diambil dikeringkan pada temperatur ruang selama 3 sampai 4 hari. Pengeringan dilakukan agar uap air yang terkandung dalam sampel menjadi berkurang. Sampel yang telah kering kemudian digerus hingga halus menggunakan lumpang dan alu, setelah itu diayak menggunakan ayakan 100 mesh. Sampel tanah kemudian dimasukkan ke dalam sample holder. Selanjutnya dilakukan pengukuran suseptibilitas magnetik sampel menggunakan Bartington Magnetic Susceptibility Meter MS2 dengan sensor MS2B 
menggunakan 15 arah pengukuran. Data dari hasil pengukuran diolah menggunakan program Matlab 2015a untuk memperoleh nilai suseptibilitas magnetik sampel, kemudian dilakukan pemetaan kontur menggunakan program Surfer 11 untuk mengetahui sebaran nilai suseptibilitas magnetiknya. Penentuan jenis dan konsentrasi logam berat dilakukan terhadap lima sampel uji di Laboratorium Kimia Instrumen Universitas Negeri Padang menggunakan X-Ray Fluorescence Panalytical Epsilon 3.

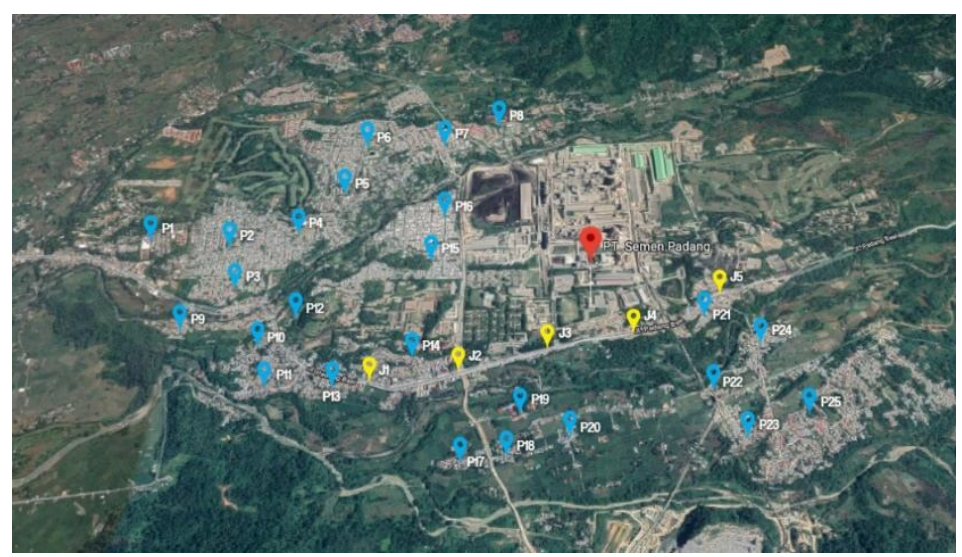

Gambar 1 Peta lokasi pengambilan sampel

\section{HASIL DAN DISKUSI}

\subsection{Sebaran Nilai Suseptibilitas Magnetik Sampel Tanah}

Tabel 1 Nilai suseptibilitas magnetik sampel tanah

\begin{tabular}{|c|c|c|c|c|}
\hline No. & $\begin{array}{c}\text { Kode } \\
\text { Sampel }\end{array}$ & $\begin{array}{l}\text { Koordinat } \\
\text { Lintang }\left(^{\circ}\right)\end{array}$ & $\begin{array}{l}\text { Koordinat } \\
\text { Bujur }\left(^{\circ}\right)\end{array}$ & $\begin{array}{c}\text { Suseptibilitas } \\
\text { Magnetik }\left(10^{-8} \mathrm{~m}^{3} / \mathrm{kg}\right)\end{array}$ \\
\hline 1 & $\mathrm{~J} 1$ & $-0,957955$ & 100,459426 & 1565,0 \\
\hline 2 & $\mathrm{~J} 2$ & $-0,957389$ & 100,463519 & 1210,6 \\
\hline 3 & $\mathrm{~J} 3$ & $-0,956133$ & 100,467653 & 1079,9 \\
\hline 4 & $\mathrm{~J} 4$ & $-0,955442$ & 100,471707 & 2218,9 \\
\hline 5 & J5 & $-0,953370$ & 100,475926 & 989,3 \\
\hline 6 & $\mathrm{P} 1$ & $-0,948858$ & 100,447227 & 514,1 \\
\hline 7 & $\mathrm{P} 2$ & $-0,949433$ & 100,451448 & 841,3 \\
\hline 8 & P3 & $-0,952332$ & 100,452257 & 427,3 \\
\hline 9 & P4 & $-0,948671$ & 100,454878 & 319,9 \\
\hline 10 & P5 & $-0,945982$ & 100,456774 & 740,2 \\
\hline 11 & P6 & $-0,942238$ & 100,457960 & 725,0 \\
\hline 12 & P7 & $-0,942346$ & 100,462315 & 728,2 \\
\hline 13 & P8 & $-0,940782$ & 100,465564 & 775,5 \\
\hline 14 & P9 & $-0,954682$ & 100,450013 & 488,3 \\
\hline 15 & P10 & $-0,955848$ & 100,453997 & 776,1 \\
\hline 16 & $\mathrm{P} 11$ & $-0,958159$ & 100,454731 & 655,7 \\
\hline 17 & P12 & $-0,954139$ & 100,455583 & 487,8 \\
\hline 18 & P13 & $-0,958189$ & 100,457779 & 720,2 \\
\hline 19 & P14 & $-0,956515$ & 100,461326 & 694,4 \\
\hline 20 & P15 & $-0,950581$ & 100,462050 & 729,2 \\
\hline 21 & P16 & $-0,947633$ & 100,462632 & 449,4 \\
\hline 22 & P17 & $-0,962087$ & 100,463721 & 225,7 \\
\hline 23 & P18 & $-0,961828$ & 100,465721 & 601,0 \\
\hline 24 & P19 & $-0,959829$ & 100,466403 & 416,5 \\
\hline 25 & $\mathrm{P} 20$ & $-0,960932$ & 100,468510 & 385,8 \\
\hline 26 & $\mathrm{P} 21$ & $-0,954641$ & 100,474975 & 617,2 \\
\hline 27 & $\mathrm{P} 22$ & $-0,958536$ & 100,474789 & 250,7 \\
\hline 28 & $\mathrm{P} 23$ & $-0,961030$ & 100,476143 & 477,0 \\
\hline 29 & $\mathrm{P} 24$ & $-0,956252$ & 100,477473 & 213,9 \\
\hline 30 & $\mathrm{P} 25$ & $-0,959994$ & 100,478829 & 281,4 \\
\hline
\end{tabular}


Posisi geografis dan hasil pengolahan data suseptibilitas magnetik sampel tanah dari 30 titik pengambilan sampel di lokasi penelitian dapat dilihat pada Tabel 1. Pada jalan utama nilai suseptibilitas magnetik berkisar antara $989,3 \times 10^{-8} \mathrm{~m}^{3} / \mathrm{kg}$ sampai $2218,9 \times 10^{-8} \mathrm{~m}^{3} / \mathrm{kg}$ dengan nilai rata-rata $1412,7 \times 10^{-8} \mathrm{~m}^{3} / \mathrm{kg}$. Pada pemukiman penduduk nilai suseptibilitas magnetik berkisar antara $213,9 \times 10^{-8} \mathrm{~m}^{3} / \mathrm{kg}$ sampai $841,3 \times 10^{-8} \mathrm{~m}^{3} / \mathrm{kg}$ dengan nilai rata-rata $541,7 \times 10^{-8} \mathrm{~m}^{3} / \mathrm{kg}$. Nilai suseptibilitas magnetik secara keseluruhan berkisar antara $213,9 \times 10^{-8} \mathrm{~m}^{3} / \mathrm{kg}$ sampai $2218,9 \times 10^{-8}$ $\mathrm{m}^{3} / \mathrm{kg}$ dengan nilai rata-rata $686,9 \times 10^{-8} \mathrm{~m}^{3} / \mathrm{kg}$.

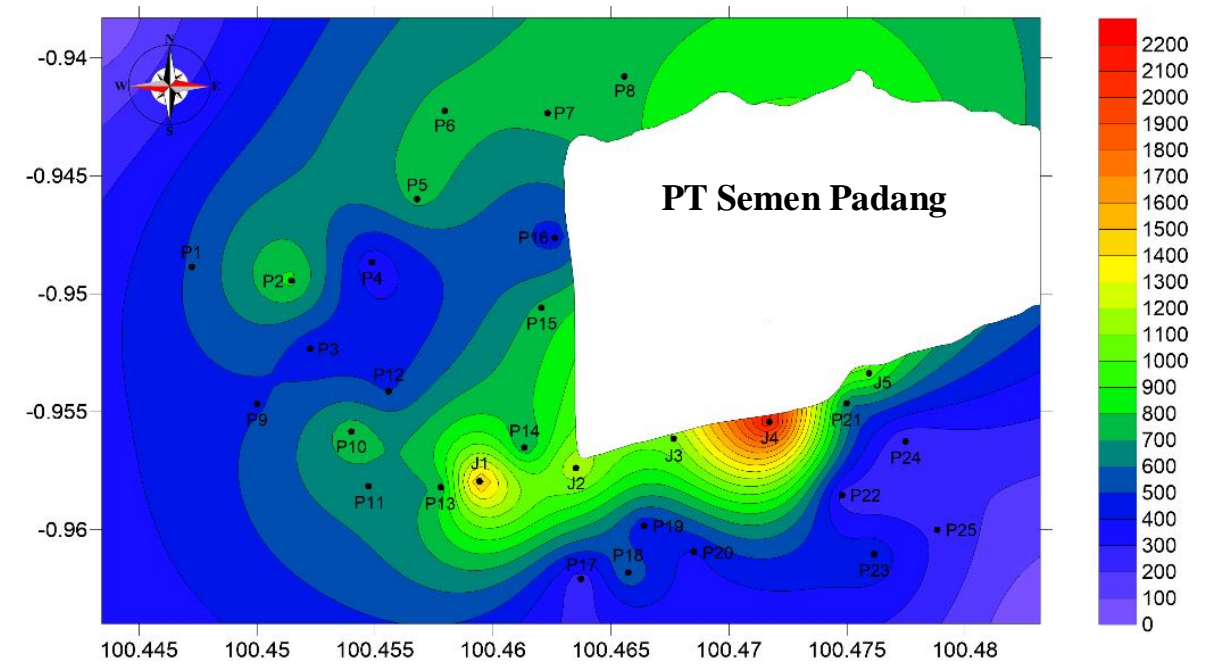

Gambar 2 Peta kontur sebaran nilai suseptibilitas magnetik pada 30 titik sampel

Berdasarkan nilai suseptibilitas magnetik sampel dapat dilakukan pemetaan kontur seperti pada Gambar 2. Pada gambar tersebut dapat dilihat bahwa sebaran nilai suseptibilitas magnetik tertinggi berada pada daerah di sebelah sisi Selatan PT Semen Padang. Daerah tersebut berada di pinggir jalan lintas utama Padang-Solok yang banyak dilalui oleh kendaraan bermotor. Tingginya nilai suseptibilitas magnetik pada daerah tersebut disebabkan oleh logam berat yang diperkirakan berasal dari emisi pabrik PT Semen Padang dan emisi kendaraan bermotor. Selain daerah yang berada di pinggir jalan utama, sebaran nilai suseptibilitas magnetik tertinggi pada pemukiman penduduk berada di sisi Utara PT Semen Padang. Hal ini disebabkan karena daerah di sisi Utara berdekatan dengan pabrik pengolahan semen PT Semen Padang. Sebaran nilai suseptibilitas magnetik ke arah Barat dari PT Semen Padang semakin menurun, namun pada titik P2 mengalami peningkatan nilai suseptibilitas magnetik. Hal tersebut dikarenakan pengambilan sampel pada titik P2 berada dekat dengan jalan utama, sehingga menyebabkan logam berat yang terkandung dalam sampel diperkirakan juga berasal dari kendaraan bermotor.

\subsection{Hubungan Suseptibilitas Magnetik dan Total Konsentrasi Logam Berat}

Uji XRF dilakukan terhadap lima sampel dari nilai suseptibilitas magnetik terendah hingga tertinggi yaitu P24, P16, P14, J2, dan J4, dimana teridentifikasi 33 macam unsur logam berat. Logam berat yang dianalisis pada penelitian ini adalah delapan unsur logam berat yang berasal dari emisi pabrik semen seperti pada Tabel 2.

Tabel 2 Konsentrasi logam berat

\begin{tabular}{ccccccccccc}
\hline $\begin{array}{c}\text { Kode } \\
\text { Sampel }\end{array}$ & $\begin{array}{c}\text { Suseptibilitas } \\
\text { Magnetik }\end{array}$ & \multicolumn{8}{c}{ Konsentrasi Logam Berat (ppm) } \\
& $\left.\mathbf{1 0}^{-8} \mathbf{m}^{\mathbf{3}} / \mathbf{k g}\right)$ & $\mathbf{C d}$ & $\mathbf{C o}$ & $\mathbf{C r}$ & $\mathbf{C u}$ & $\mathbf{F e}$ & $\mathbf{N i}$ & $\mathbf{P b}$ & $\mathbf{Z n}$ & \multirow{2}{*}{ Total } \\
\hline P24 & 213,9 & - & - & 70 & 140 & 52660 & - & $50^{*}$ & 420 & 53340 \\
P16 & 449,4 & - & - & 160 & 320 & 93140 & 20 & 130 & 790 & 94560 \\
P14 & 694,4 & - & - & 160 & 250 & 90760 & 50 & 150 & 1090 & 92460 \\
J2 & 1210,6 & - & - & 290 & 500 & 106300 & 70 & 110 & 760 & 108030 \\
J4 & 2218,9 & - & - & 140 & 250 & 167510 & 60 & 150 & 410 & 168520 \\
\hline
\end{tabular}

*) Konsentrasi logam berat yang belum mencapai ambang batas 
Dari Tabel 2 dapat dilihat bahwa kandungan unsur logam berat Co tidak ditemukan pada kelima sampel uji yang diambil di lokasi penelitian. Pada penelitian Afdal dan Yulius (2012) diperoleh nilai konsentrasi logam berat Cd pada sampel J2 sebesar 50 ppm dan sampel J4 sebesar 47 ppm. Kedua nilai konsentrasi tersebut sudah melebihi nilai ambang batas, dimana nilai ambang batas logam berat $\mathrm{Cd}$ di dalam tanah adalah $0,5 \mathrm{ppm}$. Pada penelitian ini kandungan unsur logam berat $\mathrm{Cd}$ tidak terdeteksi pada kelima sampel uji. Hal ini menunjukkan bahwa kandungan unsur logam berat $\mathrm{Cd}$ memiliki nilai yang sangat kecil atau mendekati nol.

Grafik hubungan antara total konsentrasi logam berat dan nilai suseptibilitas magnetik pada kelima sampel uji dapat dilihat pada Gambar 3. Dari perhitungan regresi linier untuk hubungan tersebut diperoleh persamaan sebagai berikut

$$
y=50,447 x+55082
$$

dengan $x$ adalah nilai suseptibilitas magnetik $\left(10^{-8} \mathrm{~m}^{3} / \mathrm{kg}\right), y$ adalah konsentrasi logam berat (ppm), dan diperoleh nilai koefisien korelasi sebesar 0,962. Nilai ini menunjukan hubungan yang kuat antara suseptibilitas magnetik dengan kandungan logam berat. Selanjutnya akan dianalisis hubungan antara nilai suseptibilitas magnetik dengan kandungan logam berat $\mathrm{Cr}, \mathrm{Cu}$, $\mathrm{Fe}, \mathrm{Ni}, \mathrm{Pb}$, dan $\mathrm{Zn}$.

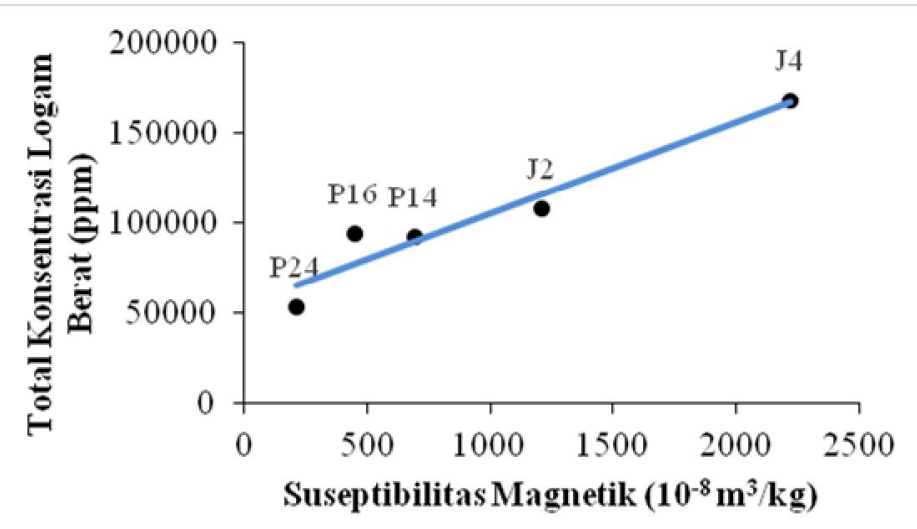

Gambar 3 Grafik hubungan total konsentrasi logam berat terhadap nilai suseptibilitas magnetik sampel

\subsection{Hubungan Suseptibilitas Magnetik dan Konsentrasi Masing-Masing Logam Berat}

Grafik hubungan antara konsentrasi logam berat $\mathrm{Cr}, \mathrm{Cu}, \mathrm{Fe}, \mathrm{Ni}, \mathrm{Pb}$, dan $\mathrm{Zn}$ terhadap nilai suseptibilitas magnetik masing-masing sampel dapat dilihat pada Gambar 4. Koefisien korelasi berturut-turut sebesar 0,$294 ; 0,259 ; 0,963 ; 0,755 ; 0,563$; dan $-0,319$. Dikarenakan sebagian besar nilai koefisien korelasinya tidak mendekati satu maka persamaan regresi linier pada grafik tidak dapat digunakan untuk menentukan konsentrasi masing-masing logam berat dari nilai suseptibilitas magnetiknya. Walau bagaimanapun nilai suseptibilitas magnetik dan konsentrasi masing-masing logam berat dari kelima sampel mempunyai korelasi yang positif, kecuali untuk logam berat $\mathrm{Zn}$ dengan korelasi yang negatif.

Untuk sampel P24 dengan nilai suseptibilitas magnetik terendah yaitu $213,9 \times 10^{-8} \mathrm{~m}^{3} / \mathrm{kg}$ dengan konsentrasi logam berat $\mathrm{Cr}, \mathrm{Cu}, \mathrm{Fe}$, dan $\mathrm{Zn}$ berturut-turut sebesar $70 \mathrm{ppm}, 140$ ppm, $52660 \mathrm{ppm}$, dan $420 \mathrm{ppm}$. Sampel tersebut telah melebihi ambang batas logam berat di dalam tanah yaitu sebesar 2,5 ppm (Cr), $125 \mathrm{ppm}(\mathrm{Cu}), 280 \mathrm{ppm}(\mathrm{Fe})$, dan $70 \mathrm{ppm}(\mathrm{Zn})$. Akan tetapi pada sampel P24 tidak terdeteksi logam berat $\mathrm{Ni}$ dan logam berat $\mathrm{Pb}$ memiliki konsentrasi di bawah ambang batas yaitu $50 \mathrm{ppm}$. Untuk sampel P16 dengan nilai suseptibilitas magnetik $449,4 \times 10^{-8} \mathrm{~m}^{3} / \mathrm{kg}$ memiliki konsentrasi logam berat $\mathrm{Ni}$ dan $\mathrm{Pb}$ sebesar $20 \mathrm{ppm}$ dan $130 \mathrm{ppm}$ yang telah melebihi ambang batas logam berat tersebut di dalam tanah yaitu sebesar $20 \mathrm{ppm}$ (Ni) dan 100 ppm (Pb). 


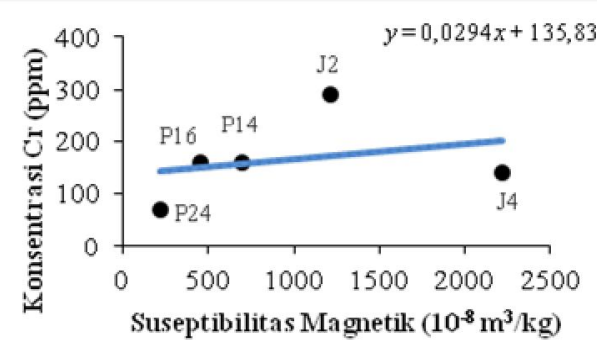

(a)

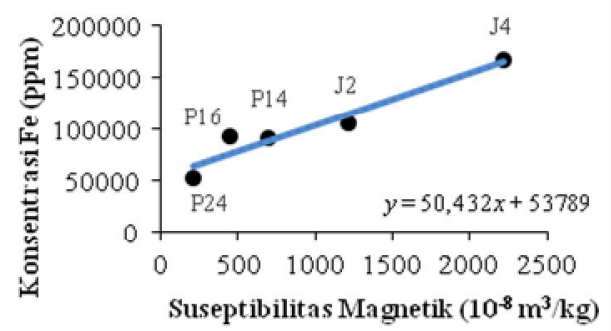

(c)

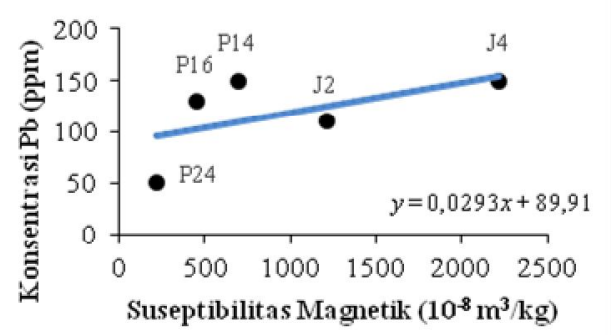

(e)

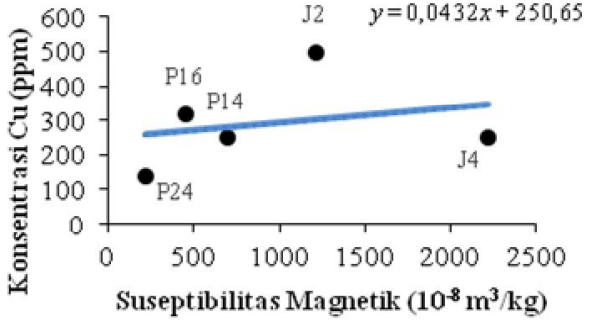

(b)

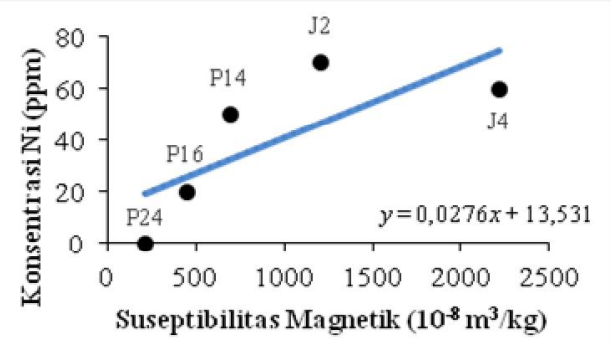

(d)

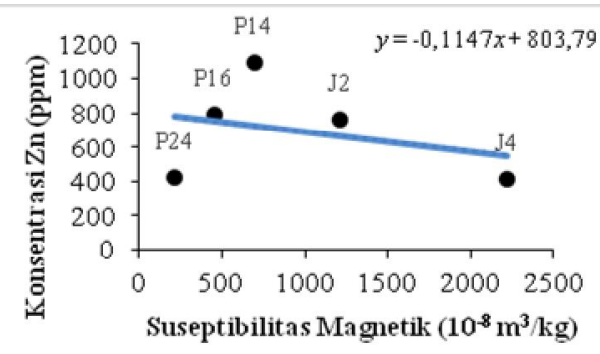

(f)

Gambar 4 Grafik hubungan konsentrasi logam berat (a) $\mathrm{Cr}$ (b) $\mathrm{Cu}$ (c) $\mathrm{Fe}$ (d) $\mathrm{Ni}$ (e) $\mathrm{Pb}$ (f) $\mathrm{Zn}$ terhadap nilai suseptibilitas magnetik masing-masing sampel

\subsection{Laju Peningkatan Pencemaran Logam Berat}

Pada penelitian ini titik pengambilan sampel yang sama dengan penelitian sebelumnya (Afdal dan Yulius, 2012) berada pada titik J2 dan J4. Perbandingan hasil penelitian kedua sampel dapat dilihat pada Tabel 3. Nilai suseptibilitas untuk sampel J2 mengalami peningkatan sebesar 11,8\% dari penelitian sebelumnya, sedangkan untuk sampel J4 mengalami peningkatan sebesar $0,05 \%$. Peningkatan nilai suseptibilitas magnetik ini disebabkan oleh bertambahnya konsentrasi logam berat yang terdapat pada sampel selama enam tahun terakhir. Hal ini ditunjukkan oleh hasil uji XRF, dimana hampir seluruh konsentrasi logam berat mengalami peningkatan, kecuali logam berat Cd yang tidak ditemukan pada kelima sampel uji.

Tabel 3 Perbandingan suseptibilitas magnetik dan konsentrasi logam berat

\begin{tabular}{|c|c|c|c|c|c|c|c|c|c|c|c|c|}
\hline \multirow{3}{*}{$\begin{array}{l}\text { Kode } \\
\text { Sampel }\end{array}$} & \multicolumn{12}{|c|}{ Suseptibilitas } \\
\hline & \multicolumn{2}{|c|}{$\begin{array}{c}\text { Magnetik } \\
\left(10^{-8} \mathrm{~m}^{3} / \mathrm{kg}\right)\end{array}$} & \multicolumn{10}{|c|}{ Konsentrasi Logam Berat (ppm) } \\
\hline & $\square *$ & $\square$ & $\mathbf{C d}^{*}$ & Cd & Cr* & $\mathrm{Cr}$ & $\mathbf{C u}^{*}$ & $\mathbf{C u}$ & $\mathbf{P b}^{*}$ & $\mathbf{P b}$ & $\mathbf{Z n} *$ & $\mathbf{Z n}$ \\
\hline $\mathrm{J} 2$ & 1082,9 & 1210,6 & 50 & - & 35,3 & 290 & 56,9 & 500 & 41,5 & 110 & 67,5 & 760 \\
\hline $\mathrm{J} 4$ & 2217,7 & 2218,9 & 47 & - & 36,2 & 140 & 96,9 & 250 & 26,4 & 150 & 107,5 & 410 \\
\hline
\end{tabular}

*) Data pada penelitian Afdal dan Yulius (2012) 


\section{KESIMPULAN}

Berdasarkan hasil penelitian dapat disimpulkan bahwa nilai suseptibilitas mangnetik sampel berkisar dari $213,9 \times 10^{-8} \mathrm{~m}^{3} / \mathrm{kg}$ (P24) sampai $2218,9 \times 10^{-8} \mathrm{~m}^{3} / \mathrm{kg}$ (J4) dengan rata-rata $686,9 \times 10^{-8} \mathrm{~m}^{3} / \mathrm{kg}$. Dari pemetaan nilai suseptibilitas magnetik diketahui bahwa penyebaran nilai suseptibilitas magnetik yang tinggi berada pada daerah di sebelah sisi Selatan PT Semen Padang. Daerah tersebut mengandung logam berat yang tinggi karena berada di pinggir jalan lintas utama Padang-Solok yang banyak dilalui kendaraan bermotor. Hasil XRF menunjukkan bahwa kelima sampel uji (P24, P16, P14, J2, dan J4) mengandung logam berat $\mathrm{Cr}, \mathrm{Cu}, \mathrm{Fe}, \mathrm{Ni}$, $\mathrm{Pb}$, dan $\mathrm{Zn}$ yang melebihi ambang batas, kecuali pada sampel $\mathrm{P} 24$ untuk logam berat $\mathrm{Ni}$ dan $\mathrm{Pb}$.

Berdasarkan hubungan antara nilai suseptibilitas magnetik dan konsentrasi logam berat pada kelima sampel uji, dapat dikatakan bahwa sebagian besar dari seluruh sampel yang diambil di sekitar pabrik PT Semen Padang mengandung logam berat yang telah melebihi ambang batas. Logam berat yang terkandung dalam sampel diperkirakan berasal dari emisi pabrik PT Semen Padang, mengingat sampel yang diambil di pemukiman penduduk sebagian besar mengandung logam berat yang telah melebihi ambang batas dan tidak terdapatnya sumber lain. Nilai suseptibilitas magnetik dan konsentrasi logam berat mengalami peningkatan dari penelitian sebelumnya (Afdal dan Yulius, 2012), kecuali logam berat Cd karena tidak ditemukan pada kelima sampel uji.

\section{DAFTAR PUSTAKA}

Afdal dan Yulius, U., "Suseptibilitas Magnetik dan Kontaminasi Logam Berat dalam Tanah Lapisan Atas di Sekitar Pabrik Semen di Kota Padang", Jurnal Ilmu Fisika (JIF), 4, 76 82 (2012).

Al-Khashman, O.A. dan Shawabkeh, R.A., "Metals Distribution in Soils Around the Cement Factory in Southern Jordan”, Environmental Pollution, 140, 387-394 (2006).

Bermudez, G.M.A., Moreno, M., Invernizzi, R., Plá, R., dan Pignata, M.L., "Heavy Metal Pollution in Topsoils Near a Cement Plant: the Role of Organic Matter and Distance to the Source to Predict Total and HCl-Extracted Heavy Metal Concentrations", Chemosphere, 78, 375-381 (2010).

Brempong, F., Mariam, Q., dan Preko, K., "The Use of Magnetic Susceptibility Measurements to Determine Pollution of Agricultural Soils in Road Proximity", African Journal of Environmental Science and Technology, 10, 263-271 (2016).

Kucer, N., Sabikoglu, I., dan Can, N., "Measurements of Environmental Pollution in Industrial Area Using Magnetic Susceptibility Method", Acta Physica Polonica A, 121, 20-22 (2012).

Lu, S., Wang, H., dan Guo, J., 2010, "Magnetic Response of Heavy Metals Pollution in Urban Soils: Magnetic Proxy Parameters as an Indicator of Heavy Metals Pollution", 19th World Congress of Soil Science, Hangzhou, China.

Ogunkunle, C.O. dan Fatoba, P.O., "Contamination and Spatial Distribution of Heavy Metals in Topsoil Surrounding a Mega Cement Factory", Atmospheric Pollution Research, 5, 270-282 (2014).

Radojević, M. dan Bashkin, V.N., Practical Environmental Analysis (The Royal Society of Chemistry, United Kingdom, 1999).

Rochyatun, E. dan Rozak, A., "Pemantauan Kadar Logam Berat dalam Sedimen di Perairan Teluk Jakarta", Makara Sains, 11, 28-36 (2007).

Sutanto, R., Dasar-Dasar Ilmu Tanah (Kanisius, Yogyakarta, 2005).

Wang, X.S., "Assessment of Heavy Metal Pollution in Xuzhou Urban Topsoils by Magnetic Susceptibility Measurements", Journal of Applied Geophysics, 92, 76-83 (2013).

Worsztynowicz, A. dan Mill, W., "Potential Ecological Risk Due to Acidification of Heavy Industrialized Areas the Upper Silesia Case", Acid Rain Research, 353-365 (1995). 